\title{
IMPLEMENTASI SUPERVISI PENDIDIKAN DALAM MENINGKATKAN PROSES PEMBELAJARAN
}

\section{Oleh:}

Ratih Hendriawati

Ratihhendriawati0508@gmail.com

\section{Kata Kunci : Supervisi, Kepala Sekolah, Guru}

\begin{abstract}
ABSTRAK
Supervisi disekolah dilaksanakan oleh kepala sekolah yang bertindak sebagai supervisor, maka ia harus mampu melakukan berbagai pengawasan dan pengendalian untuk meningkatkan kinerja guru. Pengawasan dan pengendalian merupakan tindakan preventive untuk mencegah agar guru tidak melakukan penyimpangan dan lebih berhati-hati dalam melaksanakan pekerjaannya sebagai pendidik. Oleh karena itu, dalam artikel ini mengungkapkan kegiatan supervisi yang dilakukan oleh kepala sekolah Min Sukadamai kota banda aceh terhadap kinerja guru. Adapun hasil dari yang terdapat dalam artikel ini adalah 1). Fokus kegiatan supervisi yang dilakukan kepala sekolah dapat diidentifikasikan kedalam dua hal yaitu: kegiatan supervisi yang menyangkut administrasi guru dan kegiatan proses belajar mengajar 2). Kegiatan supervisi sangat membantu bagi guru memecahkan masalah-masalah pendidikan yang dihadapi guru pada saat melakukan pembelajaran, serta dapat memberikan motivasi bagi guru agar selalu meningkatkan pengetahuan untuk menjadi guru yang profesioanl dalam melaksanakan pembelajaran. 3). Hambatan kepala sekolah dalam supervisi adalah tumpang tindih kegiatan dan keterbatasan dana operasional.
\end{abstract}

\section{A.Latar Belakang}

\section{Pentingnya supervisi dan Kondisi supervisi disekolah saat ini}


Guru memiliki potensi untuk berkreasi dan meningkatkan kinerjanya. Namun demikian seringkali banyak faktor yang menghambat mereka dalam mengembangkan berbagai potensinya secara optimal baik itu berupa kemampuan guru itu sendiri dalam proses belajar mengajar, maupun sarana dan prasaranan pendidikan yang tersedia. Mengingat hal tersebut sangat dirasakan perlunya supervisi yang berkesinambungan dengan program yang terarah dan sistematis terhadap guru. Program supervisi guru tersebut lazim disebut supervisi yang merupakan suatu rangkaian penting dalam manajemen pendidikan.

Adapun fungsi utama dari supervisi pendidikan seperti yang dikemukanan oleh Sahertian, bahwa fungsi dasar dari supervisi adalah untuk mempervaiki situasi belajar mengajar disekolah agar lebih baik. Supervisi terhadap proses belajar mengajar, merupakan salah satu bentuk aktivitas yang direncanakan untuk membantu para guru dalam melakukan pekerjaan yang direncanakan untuk membantu para guru dalam melakukan pekerjaan mereka secara efektif.

Kompetensi guru saat ini harus ditingkatkan lagi agar harkat dan martabat guru tidak dilecehkan lagi. Peningkatan komptensi ini tidak hanya dilakukan sekali saja tetapi harus dilakukan terus menerus dan mendapat perhatian yang serius dari pemerintah dan sistem pendidikan. Kompetensi guru yang prlu ditingkatkan seperti kompetensi pendidikan (pedagogig) hubungan sosial profesionalisme dan kepribadian dari guru tersebut.

Budaya sekolah secaara umum terbentuk atas dasar Visi dan misi seseorang yang dikembangkan sebagai adaptasi terhadap tuntutan lingkungan (masyarakat) baik internal maupun eksternal. Setiap sekolah sendiri sebagai identitas diri juga sebagai rasa kebanggaan akan sekolahnya. Buda sekolah merupakan ciri khas, karakter atau watak dan citra sekolah tersebut dimasyarakat luas. Kerja sama yang terjalin antar anggota memiliki unsur visi dan misi, sumber daya, dasar hukum struktur dan anatomi yang jelas dalam ranga mencapai tujuan tertentu merupakan organisasi 
secara formal. Pentingnya membangun budaya sekolag terutama berkenaan dengan upaya pencapaian tujuan pendidikan sekolah dan peningkatan kinerja sekolah.

Kegiatan pengembangan diri terutama bagaimana setiap anggota kelompok disekolag berusaha memperbaiki diri dan meningkatkan mutu pekerjaannya merupakan kultur yang hidup sebagai tradisi yang tidak dianggap sebagai suatu beban kerja. Begitu juga halnya dengan supervisi dalam usaha meningkatkan mutu pembelajaran, bila telah membudaya, guru yaang melaksanakannya tidak lagi menganggap bahwa pembinaan, pengawasan dan supervisi, bukan merupakan suatu paksaan yang datang dari luar dirinya melainkan tradisi akademik yang dijunjung tinggi karena berguna buat sekolah secara keseluruhan.

\section{Rumusan Masalah}

1. Apakah Supervisi Pendidikan itu dan bagaimana pentingnya terkait dunia pendidikan

2. Bagaimana kepala sekolah mengimplementasikan dirinya sebagai supervisor

3. Bagaimana penyusunan program supervisi pendidikan disekolah tersebut

4. Bagaimana supervisi Pendidikan dan pengembangan sumber daya guru yang ada disekolah tersebut

\section{Tujuan Penulisan}

1. Untuk memenuhi tugas akhir mata kuliah Supervisi Pendidikan

2. Untuk mengetahui Bagaimana implementasi supervisi pendidikan disuatu sekolah

3. Untuk mengetahui bagaimana kinerja kepala sekolah sebagai seorang supervisor

4. Untuk mengetahui bagaimana kinerja seorang guru dalam mensukseskan penyusunan program supervisi pendidikan disekolah tersebut. 


\section{B. Kajian Literatur}

Kata supervisi berasal dari bahasa inggris yaitu supervision, terdiri atas dua kata, yaitu super dan vision yang mengandung pengertian melihat dengan sangat teliti pekerjaan secara keseluruhan, orang yang melakukan supervisi disebu supervisor. Suharsimi menjelaskan, bahwa supervisi terdiri dari dua kata yaitu: Super dan vision yang berarti melihat, maka secara keseluruhan supervisi diartikan sevagai melihat dari atas, dengan pengertian itulah supervisi dikatakan sebagai kegiatan yang dilakukan oleh kepala sekolah sebagai pejabat yang berkedudukan diatas lebih tinggi dari guru untuk melihat dengan teliti pekerjaan secara keseluruhan atau mengawasi pekerjaan guru.

Pengertian supervisi dalam kaitannya dengan pendidikan adalah pembinaan guru. Konsep supervisi tradisional menganggap supervisi sebagai inspeksi. Hal inilah yang menyebabkan guru merasa takut dan tidak bebas melakukan tugasnya serta merasa terancam dan merasa takut untuk bertemu dengan supervisor, bahkan supervisor dianggap tidak memberikan dorongan bagi kemajuan guru. Sikap tersebut dipengaruhi oleh pemahaman tentang supervisi secara tradisional, artinya supervisor dipahami sebagai pengawasan dalam pengertian mencari-cari kesalahan dan menemukan kesalahan untuk diperbaiki yang pada gilirannya mempengaruhi penilaian terhadap guru. Dalam pengertian lain, supervisi merupakan peningkatan makna dari inspeksi yang berkonotasi mencari-cari kesalahan, jelaslah bahwa kesan seperti itu sangat kurang tepat dan tidak sesuai lagi dengan zaman reformasi seperti sekarang ini.

Supervisi pendidikan berkembang seiring berkembangkan ilmu manajemen. Pada awal perkembangannya, supervisi dilakukan dengan pendekatan inspeksi. Supervisor datang ke sekolah dan mengamati guru mengajar. Fokus perhatian supervisor adalah menemukan kesa berdasarkan standar kerja baku yang dirumuskan sedemikian rupa oleh otoritas pendidikan. Guru melaksanakan tugas sesuai dengan 
prosedur operasional yang standar. Supervisor dengan guru merupakan dua pihak sebagai atasan Supervisor memiliki tingkat kebenaran yang lebih tinggi dari pada guru. Seiring dengan perkembangan manajemen bahwa produktivitas ditentukan juga oleh hubungan sosial antar pekerja dan dengan supervisor. Pendekatan supervisi bergerak ke arah yang lebih demokratis; supervisor dan guru dapat saling bertukar pendapat tentang peningkatan kualitas pembelajaran. Perkembangan supervisi dewasa ini lebih menekankan kepada upaya guru untuk mengembangkan kualitas pembelajarannya melalui pengembangan keprofesionalan berkelanjutan. Sehubungan perkembangan pengetahuan dan teknologi yang berkembangan pesat dalam waktu yang sangat singkat, supervisor dengan jumlah 2 supervisi yang tepat, dan (3) menindaklanjuti hasil dap guru dalam rangka peningkatan profesionalisme guru. Disamping itu, supervisi yang dilakukan oleh pengawas diatur dalam Permen Diknas Nomor 12 Tahun 2007 tentang Standar Pengawas Sekolah/Madrasah. Dimensi kompetensi pengawas sekolah/madrasah 1) kompetensi kepribadian, (2) kompetensi supervisi manajerial, (3) kompetensi supervisi akademik, (4) kompetensi evaluasi pendidikan, (5) kompetensi penelitian pengembangan, dan (6) kompetensisosial. Berdasarkan Permen Diknas nomor 12 tahun 2007 n Diknas nomor 13 tahun 2007, bahwa kepala sekolah dan pengawas sekolah/madrasah memiliki tanggung jawab dalam meningkatkan Tujuan tulisan ini adalah mengungkapkan beberapa pendekatan supervisi yang dapat maupun pengawas dalam rangka meningkatkan profesionalitas guru.

Mengenai pengertian supervisi pendidikan, Ali Imron menjelaskan bahwa supervisi pendidikan adalah serangkaian bantuan kepada para guru, terutama bantuan yang berwujud layanan profesional untuk meningkatkan proses belajar mengajar, selanjutnya, sahertian berpendapat, bahwa supervisi pendidikan adalah sebagai pemberian pelayanan dan bantuan guru meningkatkan kualitas pendidikan.

Adapun 3 Unsur penting yang harus diperhatikan tentang supervisi pendidikan yaitu: 
1. Unsur proses pengarahan, bantuan atau pertolongan dari pihak atasan atau pihak yang lebih memahami

2. Unsur guru-guru dan personalia sekolah lainnya yang berhubungan langsung dengan belajar mengajar para siswa sebagai pihak yang diberikan pertolongan.

3. Unsur proses belajar mengajar atau situasi belajar mengajar sebagai objek yang diperbaiki.

\section{Pembahasan}

\section{Kepala Sekolah sebagai Supervisor}

Pelaksanaan supervisi pendidikan oleh kepala sekolah, maka ia harus mampu melakukan berbagai pengawasan dan pengendalian untuk meningkatkan proses belajar mengajar. Pengawasan dan pengendalian merupakan kontrol agar kegiatan pendidikan disekolah terarah sesuai tujuan yang telah ditetapkan. Pengawasan dan pengendalian juga merupakan tindakan pencegahan agar para guru tidak melakukan penyimpangan dan lebih berhati-hati dalam melaksanakan tugasnnya.

Dalam melaksanakan tugasnnya, supervisi berfungsi membantu, memberi suport dan mengajak serta mengikut sertakan guru dalam memperbaiki proses belajar mengajar. Dilihat dari fungsinya, tampak dengan jelas perenana supervisi itu dapat membantu guru dalam melengkapi kesulitan belajar mengajar. Seorang supervisor dapat berperan sebagai koordinator, konsultan, pemimpin kelompok dan evaluator.

Adapun berkaitan dengan tanggung jawab supervisor dalam pendidikan dapat melaksanakan program-program supervisi terhadap terjadinya perubahandalam kegiatan pengajaran, perubahan-perubahan tersebut dapat dilakukan dengan berbagai macam pendekatan dan berbagai usaha inovasi dalam pengembangankurikulum serta kegiatan pendidikan dan pelatihan dalam jabatan untuk guru. Sesuai dengan tanggung jawab dalam melakukan tugasnnya, maka supervisor mempunyai wewenang tertentu 
sesuai dengan tugas yang dilaksanakan. Wewenang supervisor adalah melaksanakan koreksi, memperbaiki dan membina proses belajar mengajar bersama guru, sehingga proses itu mencapai hasil yang maksimal.

\section{Penyusunan Program Supervisi Pendidikan}

Pelaksanaan supervisi pendidikan dilakukan setiap awal tahun pelajaran, setiap awal semester dan pada saat berlangsungnya kegiatan proses belajar mengajar. Fokus kegiatan supervisi yang dilakukan kepala sekolah dapat diidentifikasikan kedalam dua hal yaitu: pertama, kegiatan supervisi yang menyangkut semua persiapan yang harus dipersiapkan oleh seorang guru sebelum melakukan pembelajaran dan kedua, kegiatan supervisi yang menyangkut dengan kegiatan proses belajar mengajar.

Kepala sekolah merencanakan pelaksanaan supervisi pendidikan terhadap guru-guru minimal satu kali, dan maksimal dua kali setahun, yaitu satu kali pada semester ganjil dan satu kali pada semester genap. Jadwal pelaksanaannya pada awal dan akhir semester, baik semester ganjil maupun semester genap. Hal ini dilakukan untuk melihat perkembangan dan perubahan yang dilakukan guru dalam proses belajar mengajar.Program supervisi pendidikan yang disusun oleh kepala sekolah berorientasi pada bimbingan terhadap tugas-tugas guru, seperti penyusunan program pengajaran, pelaksanaan program pengajaran, persiapan perangkat pembelajaran (Satuan acuan pelajaran), rencana pembelajaran, alat evaluasi dan persiapan media pembelajaran dan lainnya.

Upaya yang dilakukan oleh kepala sekolah dalam pelaksanaan supervii meliputi penyusunan program tahunan, program semester dan persiapan lainnya yang harus dipersiapkan oleh seorang guru, dan mengadakan kunjungan supervisi kekelas serta penyusunan laporan tindak lanjut hasil supervisi. Kepala sekolah melakukan supervisi terhadap semua komponen pendidikan sekolah.dan pelaksanaan supervisi ini dilakukan kepala sekolah dengan teknik humanistik bukan mencari-cari kesalahan, 
tetapi sungguh-sungguh membantu guru untuk dapat bekerja yang lebih bagus dan terarah dalam melaksanakan tugasnnya. Adapun teknik supervisi yang sering digunakan dalam pelaksanaan supervisi di MIN Sukadamai kota Banda Aceh adalah teknik kunjunga kelas, pembicaraan individdual, diskusi tentang masalah-masalah yang dihadapi guru yang berkaitan dengan pelaksanaan belajar mengajar.

\section{Supervisi pendidikan dan pengembangan sumber daya guru di MIN Sukadamai Kota Banda Aceh}

Upaya kepala sekolah dalam pengembangan sumber daya guru di sekolah ini adalah melalui pembinaan kemampuan guru dalam menguasai metode pembelajaran, kemampuan dalam teknik evaluasi.

a. Upaya pembinaan kemampuan guru dalam penguasaan materi ajar Kepala sekolah mengupayakan guru-guru dalam diskusi-diskusi disekolah, mengirim guru agar dapat mengikuti MGMP. Hal ini bertujuan agar dapat berdiskusi untu pendalaman materi pelajaran dan masalah masalah lain yang ditemukan dalam pembelajaran. Selanjutnya upaya kepala sekolah dalam meningkatkan sumber daya guru yaitu melalui memenuhi kebutuhan guru terhadap bahan ajar atau buku pelajaran yang diajarkan oleh masing-masing guru. Upaya yang dilakukan ini adalah agar guru memersiapkan materi dengan baik untuk dapat dijelaskan pada siswa pada saat proses pembelajaran berlangsung.

b. Upaya pembinaan kemampuan guru dalam menggunakan metode pembelajaran

Kepala sekolah melakukan supervisi yang bertujuan antara lain untuk memantau proses pembelajaran yang dilaksanakan oleh guru dalam upaya memperbaiki proses pembelajaran yang sedang dilaksanakan oleh guru. Supervisi yang dilaksanakan ini juga untuk memperoleh data tentang kekurangan, kelebihan dan kelengkapan guru, baik dari proses 
pembelajaran maupun sisi administrasi yang dipersiapkan oleh guru. Dengan melakukan supervisi dalam kegiatan pembelajaran, kepala sekolah telah melakukan upaya pembinaan profesional guru dalam melaksanakan program pembelajaran.

c. Upaya pembinaan kemampuan guru dalam teknik evaluasi pembelajaran Sistem yang diterapkan dalam sekolah ini adalah dimulai dari perencanaan evaluasi yang sesuai dengan perencanaan evaluasi yang dikembangkan dan dirancang oleh guru. Pelaksanaan evaluasi yang sesuai dengan perencanaan dapat membantu guru dalam menindaklanjuti dari hasil belajar siswa. Sedangkan untuk kepentingan guru dalam menganalisa hasil evaluasi pembelajaran, sehingga program pengayaaan atau remedial dapat dilaksanakan sesuai dengan kemampuan siswa, sehingga guru selalu diminta untuk saling berbagi pengalaman tentang evaluasi.

\section{Kesimpulan dan Saran}

\section{Kesimpulan}

Dari hasil pembahasan diatas dapat disimpulkan bahwa: Pelaksanaan supervisi pendidikan dilakukan kepala sekolah MIN sukadamai kota banda aceh didahului dengan penyusunan program supervisi yang dipersiapkan pada awal tahun ajaran. Selanjutnya dilanjutkan dengan pelaksanaan yang dilakukan setiap awal semester dan akhir semester pada saat berlangsungnya kegiatan proses belajar mengajar untuk melihat keberhasilan sejauh mana program yang telah dipersiapkan dapat terealisasikan. Fokus kegiatan supervisi yang dilakukan kepada sekolah dapat diidentifikasikan kedalam dua hal yaitu; pertama kegiatan supervisi yang menyangkut administrasi guru. Hal ini menyangkut semua persiapan yang harus dipersiapkan oleh seorang guru sebelum melakukan pembelajaran. Kedua, kegiatan supervisi menyangkut dengan kegiatan supervisi yang menyangkut dengan kegiatan proses belajar mengajar. 
Pelaksanaan supervisi pendidikan yang dilakukan oleh kepala sekolah pada MiN sukadamai kota Banda Aceh meliputi penyusunan program tahunan, kunjungan supervisi kekelas dan penyusunan laporan tindak lanjut hasil penelitian. Program tahunan disusun dengan tujuan untuk meningkatkan kualitas pendidikan melalui penilaian dan pembinaan terhadap teknis dan adminitrasi pendidikan disekolah, dan memberikan pedoman serta kejelasan bagi guru dalam rangka penyusunan program semester atau program tahunan, dan dijabarkan berdasarkan hasil rapat guru tahun sebelumnya. Kepala sekolah melakukan supervisi terhadap semua komponen pendidikan sekolah. Pelaksanaan supervisi pendidikan yang dilakukan oleh kepala sekolah lebih menekankan pada pembinaan terhadap kemampuan guru dalam mengelola pembelajaran.

Kaitan supervisi pendidikan yang dilakukan kepala sekolah terhadap proses belajar mengajar guru pada MIN sukadamai dikota Banda Aceh adalah sangat membantu bagi guru dalam memecahkan masalah-masalah pendidikan yang dihadapi guru pada saat melakukan pembelajaran, serta dapat memberikan motivasi bagi guru agar selalu meningkatkan pengetahuan untuk menjadi guru yang profesional dalam melaksanakan pembelajaran.

Hambatan yang dialami kepala sekolah MIN sukadamai dalam melaksanakan supervisi antara lain adalah sering timbulnya tumpang tindih kegiatan yang harus dilakukan kepala sekolah dalam waktu yang bersamaan sehingga program yang telah disiapkan kadang-kadang harus ditunda, karena adanya kegiatan lain yang sangat mendesak seperti rapat dinas yang harus didahului. Selanjutnnya upaya yang dilakukan adalah mencari hari lain yaitu jadwal yang tepat untuk pelaksanaan supervisi pendidikan dimaksud. Keterbatasan dana operasional sekolah untuk pembinaan guru, sehingga upaya yang ditempuh adalah melaksanakan pembinaan guru yang seyogyanya dua kali dalam setahun, mengingat keterbatasan dana, maka dilaksanakan hanya satu kali dalam setahun. 


\section{Saran}

Dalam Artikel yang dianalisis ini sebaiknya lebih banyak lagi memunculkan teori-teori yang berkaitan dengan topik atau permasalahan sehingga mendukung pembahasan atau kajian yang sedang digeluti oleh penulis.

\section{DAFTAR PUSTAKA}

Arikunto, suharsimi. (2004). Dasar-Dasar Supervisi, jakarta : Rineka Cipta

Imron, Ali. (1995) Pembinaan guru diIndonesia, Jakarta: Dunia Pustaka

Jurnal ilmiah Didaktika Vol. 16 No. 1. Agustus 2015 . Implementasi Supervisis Pendidikan Dalam meningkatkan Proses Pembelajaran di MIN Sukadamai Kota Banda Aceh oleh Cut Suryani.

PEDAGOGI | Jurnal Ilmiah Ilmu Pendidikan Volume XIII No.2 November 2013,Diterbitkan Online | http://ejournal.unp.ac.id/index.php/pedagogi Fakultas Ilmu Pendidikan Universitas Negeri Padang 